\title{
Insulin-like growth factor binding proteins in the rat uterus and their regulation by oestradiol and growth hormone
}

\author{
C. Yallampalli ${ }^{1}$, S. Rajaraman ${ }^{2}$ and M. Nagamani ${ }^{1}$ \\ ${ }^{1}$ Department of Obstetrics and Gynecology and ${ }^{2}$ Department of Pathology. The University of Texas \\ Medical Branch, Galveston, TX 77550, USA
}

\begin{abstract}
The rat uterus has previously been shown to be a site of insulin-like growth factor I (IGF-I) production and reception. The purpose of this study was to explore the possibility that the rat uterus can also hormonally regulate elaboration of IGF-binding proteins (IGFBPs). Uteri from adult ovariectomized rats were perfused, rinsed thoroughly and extracted. Western ligand blotting of SDS-polyacrylamide-fractionated uterine extracts revealed several bands of IGFBPs with molecular masses of $24,28,30-32$ and $38-42 \mathrm{kDa}$; the $28 \mathrm{kDa}$ protein was not detected in the serum. Hypophysectomy caused a marked decrease in 38-42 and 30-32 kDa proteins which was reversed by systematic treatment with growth hormone $(2 \times 120 \mu \mathrm{g}$ per rat per day for 3 days). The 28 and $24 \mathrm{kDa}$ proteins, however, were not altered by growth hormone. Oestradiol ( $1 \mu \mathrm{g}$ per rat per day for 3 days) induced more than a $50 \%$ decrease in both $38-42$ and $28 \mathrm{kDa}$ proteins, irrespective of the growth hormone status in ovariectomized rats. These studies disclose the multiplicity of uterine IGFBPs and show the ability of growth hormone and, more importantly, oestradiol to regulate these proteins. The ability of oestradiol to attenuate the IGFBPs in the uterus may enhance the access of endogenously produced IGFs to its cognate cell receptors and hence its cellular hormone action.
\end{abstract}

\section{Introduction}

Insulin-like growth factors (IGFs) are small molecular mass peptides that stimulate replication of cells in many tissues (Van Wyk, 1985). In all the extracellular and interstitial fluids analysed so far, the IGFs are complexed to high-affinity binding proteins (Hardouin et al., 1987). These IGF-binding proteins (IGFBPs) are members of a family of proteins of various sizes that are soluble, secreted by a variety of tissues and bind both IGF-I and IGF-II but not insulin (Binoux et al, 1986). Although the role(s) of tissue-derived IGFBPs is unclear, both inhibition (Ritvos et al., 1988) and stimulation (Clemmons et al., 1986) of IGF binding and action have been reported. The molecular masses for the rat IGFBPs on SDS polyacrylamide gels are: IGFBP-1, $28 \mathrm{kDa}$; IGFBP-2, 30-32 kDa and IGFBP-3, 38-45 kDa and the sequences of these three classes of rat IGFBP have been reported (Brown et al., 1989; Shimasaki et al., 1989; Murphy et al., 1990). The sequences of three more classes of rat IGFBP, IGFBP-4, -5 , and -6 have been published (Shimasaki et al., 1990; Ling et al., 1991; Shimasaki et al., 1991) with predicted molecular masses of $24,28-29$ and $21-22 \mathrm{kDa}$, respectively.

Although the relevance of IGFBPs to uterine physiology remains unclear, one of the IGFBPs, IGFBP-I, is produced by the nonpregnant human endometrium during the late secretory phase (Rutanen et al., 1986; Julkunen et al., 1989) and by decidual cells of the pregnant uterus (Rutanen et al., 1985; Julkunen et al., 1989). Expression of mRNA encoding IGFBP-2 and -3 in human endometrium (Giudice et al., 1991) and secretion of multiple

Received 11 May 1992. forms of IGFBPs by decidual cells (Clemmons et al., 1990) have been reported. In this article, we report the presence of various IGFBPs in rat uterine extracts and their modulation by growth hormone and oestradiol.

\section{Materials and Methods}

\section{Materials}

${ }^{125}$ I-labelled IGF-I was purchased from Amersham Corporation (Arlington Heights, IL); ovine growth hormone (NIADDKoGH-15) was provided by National Hormone and Pituitary Program of the National Institutes of Health (Bethesda, MD). Oestradiol, sesame oil, radioimmunoassay grade BSA and other analytical grade chemicals were purchased from Sigma Chemical Co (St Louis, MO). Ketamine (Ketalar) was purchased from Parke-Davis (Morris Plains, NJ). Recombinant IGF-I was purchased from Amgen Biologicals (Thousand Oaks, CA).

\section{Animals and treatments}

Female Sprague-Dawley rats, hypophysectomized at 200$225 \mathrm{~g}$ body weight, were obtained from Harlan-SpragueDawley Co, Houston, TX. Pituitary-intact female rats of the same strain were also obtained from Harlan-Sprague-Dawley at $150-160 \mathrm{~g}$ body weight. All the animals were housed in temperature $\left(22^{\circ} \mathrm{C}\right)$ and light controlled conditions, with free access to food and water. The hypophysectomized rats were also given $2 \%$ glucose in addition to water. 
(a)

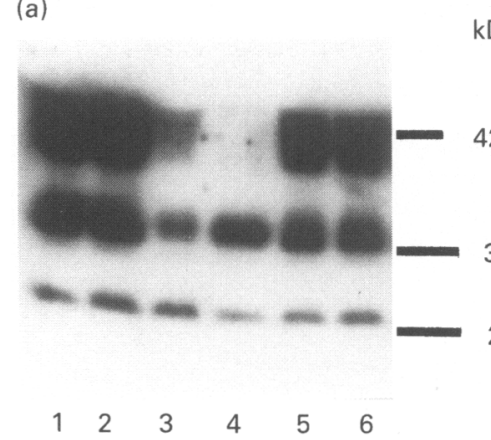

(b)

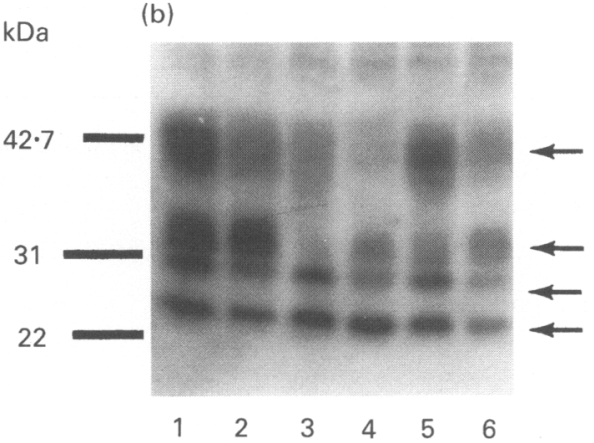

Fig. 1. Western ligand blotting of (a) serum and (b) uterine extracts from adult ovariectomized rats. Aliquots of serum $(5 \mu \mathrm{l})$ or uterine extracts $(160 \mu \mathrm{g}$ protein) were fractionated by SDS-PAGE, transferred to nitrocellulose and labelled with ${ }^{125}$ I-labelled insulin-like growth factor I (IGF-I). The nitrocellulose was exposed to X-ray film for 5 days. Each lane is from a representative animal in the pituitary-intact (lanes 1 and 2), hypophysectomized (lanes 3 and 4), or hypophysectomized plus growth hormone (lanes 5 and 6) group that received either saline (lanes 1,3 and 5) or $1 \mu$ g oestradiol (lanes 2, 4 and 6 ). The positions of 22,31 and $42.7 \mathrm{kDa}$ marker proteins are shown.

All the rats were ovariectomized under ketamine $\left(75 \mathrm{mg} \mathrm{kg}^{-1}\right.$ body weight) anaesthesia and allowed at least 7 days to recover from the surgery. At the start of injections to the animals, hypophysectomized-ovariectomized rats had been hypophysectomized for 10-14 days. Hypophysectomized-ovariectomized rats received twice daily s.c. injection of ovine growth hormone $\left(120 \mu \mathrm{g}\right.$, in $0.03 \mathrm{~mol} \mathrm{NaHCO} \mathrm{I}^{-1}$ with $0.15 \mathrm{~mol} \mathrm{NaCl}$ $\mathrm{I}^{-1}$ ) or vehicle only. The pituitary-intact ovariectomized rats received vehicle only. All these animals also received daily s.c. injection of $0.2 \mathrm{ml}$ of sesame oil with or without $1 \mu \mathrm{g}$ oestradiol. After 3 days of treatment, under ketamine anaesthesia, blood samples were collected and whole animal perfusions were carried out using heparinized saline to remove blood from the uterus. Saline was infused through a catheter placed in the jugular vein using a peristaltic pump and the perfusate was released through a puncture in the posterior vena cava.

The animals were killed and the uteri were cleaned, slit open longitudinally and rinsed thoroughly in cold Tris- $\mathrm{HCl}$ (10 $\mathrm{mmol} \mathrm{I}^{-1} \mathrm{pH} 7.4$ ), $10 \mathrm{mmol} \mathrm{MgCl}_{2} \mathrm{l}^{-1}, 1 \mathrm{mmol}$ EDTA $\mathrm{l}^{-1}$ and $0.2 \mathrm{mmol}$ phenylmethyl sulfonylfluoride $\mathrm{I}^{-1}$. Uteri from individual rats were snap frozen in liquid nitrogen and stored at $-80^{\circ} \mathrm{C}$ until used. The uteri from individual rats were homogenized in Tris- $\mathrm{HCl}$ buffer at a tissue buffer ratio of $1 \mathrm{~g}: 4 \mathrm{ml}$ with three $15 \mathrm{~s}$ bursts, at a setting of 60 in a Tekmar tissuemizer (Tekmar $\mathrm{Co}$, Cincinnati, $\mathrm{OH}$ ) with cooling intervals of $1 \mathrm{~min}$. The homogenates were centrifuged at $106000 \mathrm{~g}$ for $90 \mathrm{~min}$ and aliquots of supernatant extracts were removed for protein and haemoglobin estimation.

Insulin-like growth factor binding proteins in the uterine extracts and serum were analysed by western ligand blotting (Hossenlopp et al., 1986). Briefly, the samples were treated to $100^{\circ} \mathrm{C}$ for $5 \mathrm{~min}$ in $4 \times$ Laemmli sample buffer under nonreducing conditions and loaded onto $12 \%$ SDS polyacrylamide gels. Gel electrophoresis was performed with Protean II apparatus (Bio Rad, Richmond, CA) at $35 \mathrm{~mA}$ per gel until the dye front reached the bottom of the gel. After electrophoresis, gels washed in Towbin buffer $\left(0.025 \mathrm{~mol}\right.$ Tris-base $1^{-1}, 0.192 \mathrm{~mol}$ glycine $1^{-1}, 20 \%$ methanol) to remove SDS and proteins electroblotted onto nitrocellulose membranes $(0.5 \mu \mathrm{m})$ using Towbin buffer in a Trans-blot apparatus (BioRad) at constant $30 \mathrm{~V}$ for $16 \mathrm{~h}$ at $4^{\circ} \mathrm{C}$ (Hossenlopp et al., 1986). Membranes were washed at $4^{\circ} \mathrm{C}$ on a rocking-platform with (1) TS buffer $(150 \mathrm{mmol} \mathrm{NaCl}$ $\mathrm{I}^{-1}$ and $10 \mathrm{mmol}$ Tris- $\mathrm{HCll}^{-1}, \mathrm{pH} 7.4$, (containing $0.5 \mathrm{mg} \mathrm{NaN}_{3}$ $\mathrm{ml}^{-1}, 3 \% \mathrm{NP} 40$ ) for $30 \mathrm{~min}$; (2) TS buffer plus 1\% BSA for $2 \mathrm{~h}$; and (3) TS buffer plus $0.1 \%$ Tween- 20 for $20 \mathrm{~min}$. The membranes were incubated in a heat-sealable plastic bag with ${ }^{125}$ I-labelled IGF-I ( $1.5 \times 10^{6}$ c.p.m.) in TS buffer containing $1 \%$ BSA and $0.1 \%$ Tween-20 for $16-24 \mathrm{~h}$ at $4^{\circ} \mathrm{C}$. After incubation, membranes were washed twice with TS buffer with $0.1 \%$ Tween-20 (15 min each) and then twice with TS buffer alone, air dried and autoradiographically developed. The autoradiograms were scanned using a laser densitometer (Pharmacia LKB Instruments, Alameda, $C A)$ and absorbance units $\times$ millimetre $(\mathrm{AV} \times \mathrm{mm})$ were measured for each of the major IGFBPs. Molecular mass estimates were based on prestained protein standards (Biorad). The amount of blood contamination in the uterine extracts as determined by haemoglobin assay (Crosby and Furth, 1956) was less than $0.001 \%$.

\section{Statistical analysis}

Data were analysed using analysis of variance and the difference between means was tested using Duncan's multiple range test.

\section{Results}

\section{IGFBPs in the uterine extracts}

Ligand blot analysis of uterine extracts was performed to determine the forms of IGFBP present in the rat uterus. Autoradiographs of the nitrocellulose membranes revealed both serum and uterine extracts that contained several bands of IGFBPs. These binding proteins were specific for IGF-I, as binding was totally displaced by radioinert IGF-I $\left(100 \mu \mathrm{g} \mathrm{ml}^{-1}\right)$ (data not shown). Autoradiographs of normal rat serum revealed three major groups of IGFBPs. The most abundant group contained several bands with molecular masses ranging from 38 to $42 \mathrm{kDa}$ (Fig. 1). Since these bands were not resolved 
Table 1. Effects of growth hormone and oestradiol on different forms of insulinlike growth factor binding proteins (IGFBPs) in uterine extracts

\begin{tabular}{|c|c|c|c|c|c|}
\hline \multirow[b]{2}{*}{ Treatment group } & \multirow[b]{2}{*}{$n$} & \multicolumn{4}{|c|}{ IGFBP (scanning units) (kDa) } \\
\hline & & $38-42$ & $30-32$ & 28 & 24 \\
\hline \multicolumn{6}{|c|}{ Pituitary intact-ovariectomized } \\
\hline - Oestradiol & 4 & $314 \pm 68^{a}$ & $413 \pm 43^{b}$ & $283 \pm 23^{a}$ & $306 \pm 31^{a}$ \\
\hline +Oestradiol & 4 & $120 \pm 31^{*}$ & $381 \pm 24$ & $141 \pm 15^{*}$ & $271 \pm 40$ \\
\hline \multicolumn{6}{|c|}{ Hypophysectomized-ovariectomized } \\
\hline - Oestradiol & 4 & $106 \pm 15^{b}$ & $56 \pm 8^{b}$ & $263 \pm 26^{\mathrm{a}}$ & $301 \pm 41^{3}$ \\
\hline +Oestradiol & 4 & $53 \pm 11^{*}$ & $117 \pm 15^{*}$ & $91 \pm 12^{*}$ & $229 \pm 38$ \\
\hline \multicolumn{6}{|c|}{ Hypophysectomized-ovariectomized + growth hormone } \\
\hline - Oestradiol & 4 & $194 \pm 23^{c}$ & $110 \pm 18^{c}$ & $254 \pm 17^{a}$ & $274 \pm 4^{a}$ \\
\hline +Oestradiol & 4 & $92 \pm 12^{*}$ & $121 \pm 10$ & $62 \pm 8^{*}$ & $248 \pm 38$ \\
\hline
\end{tabular}

Values are scanning densitometric units of autoradiographs of Western ligand blots (with ${ }^{125}$ I-labelled IGF-I) presented as means \pm SEM for four animals in each group. Samples from experimental groups were run on gels on the same day and exposed together on the same radiograph.

*Significantly different $(P<0.05)$ from animals not receiving oestradiol within pituitary intact, hypophysectomized or hypophysectomized + growth hormone group. Values with different superscripts within each column differ significantly $(P<0.05)$.

completely, they were grouped for scanning densitometric analysis. The second group of IGFBPs consisted of proteins with molecular masses of $30-32 \mathrm{kDa}$. The third group consisted of a single band of $24 \mathrm{kDa}$ protein.

In uterine extracts a $28 \mathrm{kDa}$ protein was present that was not detectable in the serum from the same animals. The IGFBPs with molecular masses of $38-42,30-32$ and $24 \mathrm{kDa}$ were detected in the uterine extracts and appear to be similar in size to those in the serum (Fig. 1). The 38-42 kDa proteins in uterine extracts in all probability represent IGFBP-3 proteins. The $24 \mathrm{kDa}$ protein may represent IGFBP-4, but 28 and $30-32 \mathrm{kDa}$ proteins remain to be characterized. The immunological characterization of these various binding proteins must await the availability of specific antibodies to these proteins in rats.

\section{Regulation by growth hormone and oestradiol}

Hypophysectomy caused a marked decrease in the $38-42 \mathrm{kDa}$ proteins, the $30-32 \mathrm{kDa}$ proteins and very little change, if any, in the 24-kDa protein in rat serum (Fig. Ia: lanes 1 and 3, Table 1 ). Similar results have been reported by Yang et al. (1989). Growth hormone treatment partially restored the decreased 38-42 and $30-32 \mathrm{kDa}$ proteins. Similarly, in the uterine extracts, hypophysectomy caused a precipitous decrease in the 38-42 and $30-32 \mathrm{kDa}$ proteins and growth hormone partially restored both $38-42$ and $30-32 \mathrm{kDa}$ proteins in uterine extracts (Fig. I, Table 1). The $28 \mathrm{kDa}$ protein in the uterine extract, on the other hand, was not altered by hypophysectomy or growth hormone treatment. The amount of $24 \mathrm{kDa}$ protein in both uterine extracts and serum is not altered by the growth hormone status of the rats.

Oestradiol, at $1 \mu \mathrm{g}$ per rat, caused more than a $50 \%$ decrease in both $38-42$ and $28 \mathrm{kDa}$ proteins and no change in $24 \mathrm{kDa}$ protein in the uterine extracts of ovariectomized rats (Fig. 1;
Table 1). These effects of oestradiol were detected irrespective of the growth hormone status in these animals, indicating that oestradiol may induce downregulation of both $38-42$ and $28 \mathrm{kDa}$ IGFBP proteins. However, oestradiol induced an apparent increase $(100 \%)$ in $30-32 \mathrm{kDa}$ protein in both uterine extracts and serum of hypophysectomized-ovariectomized rats but not in pituitary-intact or growth hormone-treated hypophysectomized-ovariectomized rats. Total IGFBP activity, as determined by adding the BP activity in all IGFBP bands from each rat uterus, in the oestradiol-treated rat uterine extracts, irrespective of growth hormone status, was 30-55\% lower than that in rats not receiving oestradiol (Table 1). These effects of oestradiol on IGFBPs appeared to be specific to the uterus, as these effects were not apparent in serum.

\section{Discussion}

In this study, we examined rat uterine extracts for the presence of IGFBPs. Western ligand blotting analysis revealed several bands of specific IGFBP species with molecular masses of 38-42, $30-32,28$ and $24 \mathrm{kDa}$; the $28 \mathrm{kDa}$ protein was detected in uterine extracts but not in serum. The $38-42,30-32$ and $24 \mathrm{kDa}$ proteins in the uterine extracts were similar in size to those in serum. Although the nature and degree of relatedness between the IGFBP species in these studies remains unclear, size considerations alone would suggest that the $28,30-32,38-42$ and $24 \mathrm{kDa}$ proteins correspond to IGFBP- $-1,-2,-3$ and -4 , respectively. The resolution of the exact nature of the $28 \mathrm{kDa}$ protein is more difficult from these studies, as glycosylated IGFBP-4, IGFBP-5, glycosylated IGFBP-6 and a fragment of IGFBP-3 all run in a similar region on the gel. Complete characterization of these rodent IGFBPs in the uterus must await the availability of appropriate reagents. 
IGFBPs were considered to act as carriers for IGFs and to protect IGFs from degradation, thereby ensuring sufficient IGF supply to target tissues. The basis for this concept was that IGFs and IGFBPs were thought to be synthesized only by the liver. It is now evident that both IGFs and IGFBPs are produced by many tissues (Rutanen et al., 1986; Pekonen et al., 1988; Julkunen et al., 1989; Giudice et al., 1991). Our results extend these studies and further demonstrate that IGFBPs are extracted from rat uterus. Although the possible contribution of blood IGFBPs to that in uterine extracts cannot be excluded completely, this possibility is less likely because (1) uteri were perfused and rinsed thoroughly (Van Wyk, 1985) (2) the blood contamination in the extracts was less than $0.001 \%$ based on the haemoglobin assay (Hardouin et al., 1987) and (3) a substantial amount of $28 \mathrm{kDa}$ protein was obtained from uterine extracts while this protein was undetectable in serum (Binoux et al., 1986). We, therefore consider that these IGFBPs are produced locally and may contribute to the autocrine or paracrine modulation of IGF action in the uterus.

The observations reported here document the ability of $\mathrm{GH}$ to regulate $38-42 \mathrm{kDa}$ proteins both in uterine extracts and in serum. However, $\mathrm{GH}$ was without significant effect on $24 \mathrm{kDa}$ proteins in both serum and uterine extracts. These observations are in line with several studies demonstrating GH regulation of various IGFBPs (Clemmons et al., 1989; Glasscock et al., 1990). Growth hormone may modulate these uterine IGFBPs through its direct effects or indirectly acting through IGF-I, as has been described for some other growth hormone effects on IGFBPs. IGFBP-1 mRNA was detected in uterine epithelial cells and stromal glands and its expression during the process of decidualization was independent of the pituitary (Croze et al., 1990). Our observation that the $28 \mathrm{kDa}$ protein in the uterine extracts was not altered by $\mathrm{GH}$ status is in agreement with these studies.

The ability of oestradiol to reduce 28 and $38-42 \mathrm{kDa}$ proteins in the rat uterine extract adds another dimension to the complexity of the role of this steroid in uterine physiology, as previous studies have demonstrated that uterine IGF-I and IGF-I receptors are regulated by oestrogens (Murphy et al., 1988; Chandrasekhar et al., 1990; Murphy, 1991). An increase in the abundance of IGFBP-1 protein has been reported in the luteal phase of the menstrual cycle (Rutanen et al., 1986; Julkunen et al., 1989) in human decidual tissue (Julkunen et al., 1989; Rutanen et al., 1985) and during the first half of pregnancy (Rutanen et al., 1982; Bell and Smith, 1988). These reports together with our studies suggest that the IGFBP-I upregulation may be progesterone dependent, whereas its downregulation appears to be oestrogen dependent.

Our studies of oestrogen downregulation of $28 \mathrm{kDa}$ protein in the uterus of adult rats are in line with those reported for immature rats in which oestrogen reduced the IGFBP-1 mRNA abundance (Murphy, 1991). In addition, 38-42 kDa proteins were also reduced by oestrogens suggesting that oestrogens have regulatory effects on uterine IGFBPs. Although controversial, most of the data suggest that IGFBPs inhibit the biological actions of the IGFs. The IGF-I variants that have negligible affinity for IGFBPs are considerably more potent than IGF-I in a variety of cell culture systems (Sara and Hall, 1990). It is therefore possible that some of the oestrogen induced effects in the uterus are mediated through a decrease in IGFBP, in addition to increased IGF-I expression (Murphy, 1991), thus increasing the bioavailability and functional activity of uterine IGF-I.

In conclusion, we have demonstrated the presence of several IGFBPs in the rat uterine extracts. The $28 \mathrm{kDa}$ protein that was not detected in the serum was present in uterine extracts. Both growth hormone and oestrogens modulate the uterine IGFBP activity. Our present data that showed that oestrogens reduced uterine IGFBP activity demonstrates a modulatory role of this steroid on another component of the IGF system in this tissue. Previous studies have demonstrated the influence of oestrogens on uterine IGF-I and IGF-I receptors.

This work was supported, in part, by NIH through the Biomedical Research Support Grant-School of Medicine, UTMB (RR05427-28).

\section{References}

Bell SC and Smith S (1988) The endometrium as a paracrine organ. In Contemporary Obstetrics and Gynaecology pp 273-298 Ed. GVP Chamberlain. Butterworths, London

Binoux M, Hossenlopp P, Hardouin S, Seurin D, Lassarre C and Gourmelen M (1986) Somatomedin (insulin-like growth factors) - binding protein: molecular and regulation Hormone Research 24 141-151

Brown AL, Chiariotti L, Orlowski CC, Mehlman T, Burgess WH, Ackerman EJ, Bruni CB and Rechler MM (1989) Nucleotide sequence and expression of a cDNA clone encoding fetal rat binding protein for insulin-like growth factor Journal of Biological Chemistry 264 5148-5154

Chandrasekhar Y, Narayan S, Singh P and Nagamani M (1990) Binding of insulin-like growth factor-I to rat uterus; variations during sensitization and decidualization Acta Endocrinologica 123 243-250

Clemmons DR, Elgin RG, Han VKM, Casella SJ, D'Ercole AJ and Van Wyk JJ (1986) Cultured fibroblast monolayers secrete a protein that alters the cellular binding of somatomedin-C/insulin-like growth factor I Journal of Clinical Investigation 77 1548-1556

Clemmons DR, Thissen JP, Maes M, Ketelslegers JM and Underwood LE (1989) Insulin-like growth factor-I (IGF-I) infusion into hypophysectomized or protein-deprived rats induces specific IGF-binding proteins in serum Endocrinology 125 2967-2972

Clemmons DR, Thrailkill KM, Handwerger S and Busby WH Jr (1990) Three distinct forms of insulin-like growth factor binding proteins are released by decidual cells in culture Endocrinology 127 643-650

Crosby $W$ and Furth FW (1956) A modification of the benzidine method for measurement of hemoglobin in plasma and urine Blood 11 380-388

Croze F, Kennedy TG, Schroedter IC, Frisen HG and Murphy LJ (1990) Expression of insulin-like growth factor-I and insulin-like growth factorbinding protein-1 in the rat uterus during decidualization Endocrinology 127 1995-2000

Giudice LC, Milkowski DA, Lamson G, Rosenfeld RG and Irwin JC (1991) Insulin-like growth factor binding proteins in human endometrium; steroiddependent messenger ribonucleic acid expression and protein synthesis Joumal of Clinical Endocrinology and Metabolism 72 779-787

Glasscock GF, Gelber SE, Lamson G, McGee-Tekula R and Rosenfeld RG (1990) Pituitary control of growth in the neonatal rat: effects of neonatal hypophysectomy on somatic and organ growth, serum insulin-like growth factors (IGF)-I and -II levels and expression of IGF binding proteins Endocrinology 127 1792-1803

Hardouin S, Hossenlopp P, Segovia B, Portolan G, Lassarre C and Binoux M (1987) Heterogeneity of insulin-like growth factor binding proteins and relationships between structure and affinity. I. Circulating forms in man European Journal of Biochemistry 170 121-126

Hossenlopp P, Seurin D, Segovia-Quinson B, Harbouin S and Binoux M (1986) Analysis of serum insulin-like growth factor binding proteins using western blotting: use of the method for titration of the binding proteins and competitive binding studies Analytical Biochemistry 154 138-143

Julkunen J, Suikkari A-M, Koistinen R, Butzow R and Ritvos O (1989) Regulation of insulin-like growth factor-binding protein-I production in human granulosa-luteal cells Joumal of Clinical Endocrinology and Metabolism 69 1174-1179 
Ling N, Shimasaki S, Gao L and Shimonaka M (1991) Isolation and molecular cloning of insulin-like growth factor-binding protein-6 Molecular Endocrinology $5938-948$

Murphy LJ (1991) The uterine insulin-like growth factor system. In Modern Concepts of Insulin-Like Growth Factors pp 275-284 Ed. EM Spencer. Elsevier Science Publishers

Murphy LJ, Murphy LC and Friesen HG (1988) A role for the insulin-like growth factors as estromedins in the rat uterus Transactions Association American Physicians 99 204-214

Murphy LJ, Seneviratne C, Ballejo G, Croze F and Kennedy TG (1990) Identification and characterization of a rat decidual insulin-like growth factor binding protein cDNA Molecular Endocrinology 4 329-336

Pekonen F, Suikkari A-M, Makinen T and Rutanen E-M (1988) Different insulinlike growth factor binding species in human placenta and decidua Joumal of Clinical Endocrinology and Metabolism 67 1250-1257

Ritvos O, Tanta P, Jalkanen J, Suikkari A-M, Voutilainen R, Bohn $H$ and Rutanen E-M (1988) insulin-like growth factor (IGF) binding protein from human decidua inhibits the binding and biological action of IGF-I in cultured choriocarcinoma cells Endocrinology 122 2150-2157

Rutanen E-M, Bohn H and Seppala M (1982) Radioimmunoassay of placental protein 12: levels in amniotic fluid, cord blood and serum of healthy adults, pregnant women and patients with trophoblastic disease American Joumal of Obstetrics and Gynecology 144 460-463

Rutanen E-M, Koistinen R, Wahlstrom T, Bohn H, Ranta T and Seppala M (1985)
Synthesis of placental protein 12 by human decidua Endocrinology 116 1304-1309

Rutanen E-M, Koistinen R, Sjoberg J, Julkunen $M$, Wahlstrom T, Bohn $\mathbf{H}$ and Seppala M (1986) Synthesis of placental protein 12 by human endometrium Endocrinology 118 1067-1071

Sara VR and Hall K (1990) Insulin-like growth factors and their binding proteins Physiological Reviews 70 591-614

Shimasaki S, Koba A, Mercado M, Shimonaka M and Ling N (1989) Complementary DNA structure of the high molecular weight rat IGF-binding protein 3 and tissue distribution of its mRNA Biochemical and Biophysical Research Communications $165907-912$

Shimasaki S, Uchiyama F, Shimonaka M and Ling N (1990) Molecular cloning of the complementary DNAs encoding a novel insulin-like growth factor binding protein from rat and human Molecular Endocrinology 4 1451-1458

Shimasaki S, Shimonaka M, Zhang H-P and Ling N (1991) Identification of five different insulin-like growth factor binding proteins (IGFBPs) from adult rat serum and molecular cloning of a novel IGFBP-5 in rat and human Joumal of Biological Chemistry $26610646-10653$

Van Wyk JJ (1985) The somatomedins: biological actions and physiological control mechanisms. In Hormonal Proteins and Peptides pp 81-125 Ed. CH Li. Academic Press, Orlando

Yang YW-H, Wang J-F, Orlowski CC, Nissley SP and Rechler MM (1989) Structure, specificity, and regulation of the insulin-like growth factor-binding proteins in adult rat serum Endocrinology 125 1540-1555 